Study the Relationship Between Level of Cholesterol and Blood Group in Middle Age and Elderly Iraqi People

Hiba Abid Al-Hussein Hassan

\title{
Study the Relationship between Level of Cholesterol and Blood Group in Middle Age and Elderly Iraqi People
}

\author{
Hiba Abid Al-Hussein Hassan. \\ Collage of Health \&Medical Technology-Baghdad \\ Health Community Department
}

Received 24 April 2016

Accepted 5 June 2016

$\underline{\text { Abstract }}$

The associations amongst cholesterol levels and ABO blood groups has been established but differ in many studies. Hypercholesteremia remained powerfully associated in the progress of cardiovascular diseases. The present study was carried out to estimated cholesterol concentration and blood group in the sera samples of (100) Iraqi people at the age range (2070) years. Serum cholesterol done by auto-analyzer, while blood group by direct agglutination technique. The aim of this study to recognized whether the cholesterol level was related to ABO blood group in coronary heart disease individual. The study clarified increased concentration of cholesterol at the age (50-59 and 60-70) years other than age groups and observed that increased percentage of concentration of cholesterol in female (60\%) more than male (40\%).Also appeared that concentration of cholesterol increased at the blood group $\mathrm{A}+(33 \%)$, $\mathrm{B}+(28 \%), \mathrm{O}+(12 \%)$ and $\mathrm{AB}+(11 \%)$ compared with other blood groups. So we concluded that cholesterol level was elevated in blood group $\mathrm{A}+$ and $\mathrm{B}+$ more than other blood group.

Key words: cholesterol, blood group. 
Study the Relationship Between Level of Cholesterol and Blood Group in Middle Age and Elderly Iraqi People

\author{
Hiba Abid Al-Hussein Hassan
}

العلاقة بين مستوى الكوليسترول وصنف الام بالاعمار المتوسطة والكبار في العراقيين

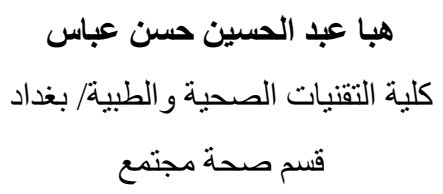

الخلاصة

ذكرت در اسات عديدة العلاقة بين مستوى الكوليستيرول واصناف الدم ولكنها تختلف من در اسة لاخرى وعلاقتة الثديدة بتطور امر اض القلب الوعائية. الدر اسة التي أجريت لقياس نسبة الكوليستيرول وصنف الدم ل 100 شخص عر اقي بمعدل الاعمار (20-70) سنة .تركيز الكولستيرول نفذ بو اسطة جهاز التحليل الذاتي بينما صنف الدم اجري بو اسطة تقنية التلازن

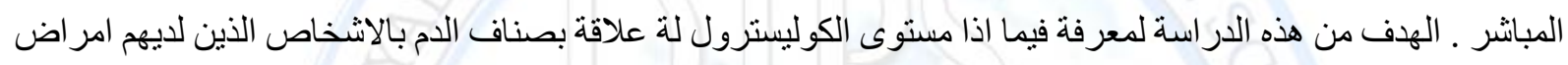
قلب و عائية .الدراسة وجدت زيادة في تركيز الكوليسترول عند الاعمار (50-59 و 60-70 ) سنة اكثر من المجاميع العمرية الأخرى ولوحظ زيادة تركيز الكوليسترول بالنساء (60\%) اكثر من الرجال (40\%) وكنلك ظهر زيادة تركيز الكوليسترول

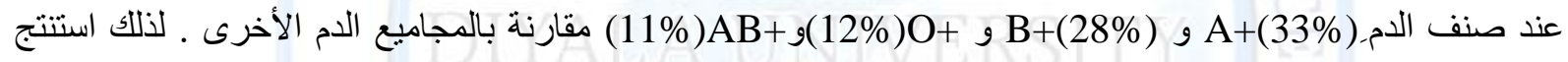
مستوى الكوليسترول يرتفع باصناف الدم BA+ و أكثر من بقية أصناف الدم .

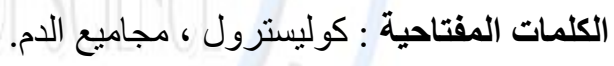

\title{
Introduction
}

Cholesterol is a sterol (or modifiedsteroid), helps in initiator and synthesis of steroidal hormones, bile acids, and vitamin D [1,2]. Greatest consumed cholesterol is esterified cholesterol and unwell absorbed. The body utilized a little absorption of further cholesterol through dipping cholesterol synthesis. For those causes, 7 to 10 hours when digestion cholesterol appearanced minute, if any, influence on whole human cholesterol contented or focuses of blood cholesterol. On the other hand, through the beginning 7 hours after absorption of cholesterol, the level significant elevated . Cholesterol was reprocessed. The liver expel cholesterol in non-esterified shape through the gastrointestinal tract. Usually almost fifty percentage of the expelled cholesterol was reabsorption by the small intestin retain to the blood $[3,4,5]$.Cholesterol is necessary to keep and build membrane. It modifies membrane flexibility above the normal value of biological temperature. The "OH group" in cholesterol interrelates 
Study the Relationship Between Level of Cholesterol and Blood Group in Middle Age and Elderly Iraqi People

\section{Hiba Abid Al-Hussein Hassan}

with the polar skull pools of the cell wall phospho-lipid, whereas large steroid and the hydrocarbon chain were bounded in the cell wall, a long side the non polar fatty acid chain of another fats. Through contact with phospholipid -fatty acid chains, cholesterol elevated membrane stuffing whom decrease membrane liquidity. Configureation of tetra-cyclic circle of cholesterol participate in the reduce liquidity of the cell wall as the molecule is in a transcon-formation action whole but side - chain of cholesterol firm . Basic role of cholesterol decline the permeability of the plasma cell wall to equal solute, hydrogen ion, and sodium ion[6,7].Inside cells, cholesterol were originator molecule in numerous biochemical passage ways. In the liver, cholesterol were transformed to bile, which is subsequently kept in the gall-bladder. Bile has bile salts, which solubilizing fats in the gastro-intestinal tract and assistance in the intestine sucking of lipid molecules as well as the fat-soluble vitamins A, D, E, and K. Cholesterol was substantial originator molecule of the creation of vitamin "D" and steroid hormones, including adrenal gland hormones "cortisol" , and aldosterone, in addition to sex- hormones "progesterone, estrogens and testosterone" and other derivatives $[8,9]$. The "ABO system" was the greatest significant blood-group system in individual blood transfusion. The related anti-A and anti-B antibodies was generally immunoglobulin $\mathrm{M}$ "IgM", antibodies. ABO IgM antibodies was formed in the $1^{\text {st }}$ years of lifetime by sensitization to environment materials for example diet, bacteria, and viruses. "The $\mathrm{O}$ in ABO is often called zero, or null"[10]. The Rhesus system $(\mathrm{Rh})$ is the $2^{\text {nd }}$ greatest important blood group system. The greatest important $\mathrm{Rh}$ antigen is the "D antigen", for the reason the maximum ready to stimulate immune system response of the 5 main rhesus system antigens. It was public for "D negative " persons not to has any "anti -D IgG or IgM antibodies", for the reason that anti-D antibodies were not commonly formed by sensitized against peripheral materials. On the other hand, D-negative person can yield IgG anti-D antibodies subsequent a immunizing results : perhaps after a fetomaternal blood transfusion to the baby in pregnancy but sometimes blood transfusion with $\mathrm{D}+\mathrm{ve}$ red blood cells. Rh disease may be progress in those conditions. Existence or lack of the rhesus system antigens is denoted by the positive or negative sign, that for example the group of $\mathrm{A}-$ see not has slightly of the rhesus system antigens[11,12]. Some information has looked in new years suggestive of relationship between "blood groups" and different appearances of 
Study the Relationship Between Level of Cholesterol and Blood Group in Middle Age and Elderly Iraqi People

\section{Hiba Abid Al-Hussein Hassan}

cardiovascular diseases. In the last few years, little information has recommended that" ABO blood groups" are related with the risk of "ischemic heart diseases "and of rising severe appearance of atherosclerosis . Whereas the battle on cholesterol have showed very productive for diet and medication manufacturing, it have brought not advantage to community condition. Heart disease was still important reason of die in western country $[3,4]$.

\section{Subjects and Methods}

The study was carried out during the period between five of October 2014 until the five of March 2015 .Subjects for study were (100) Iraqi people not suffering from any disease with age range (20-70) years attending to the hospital of Al-kark in Baghdad city .Blood sample was drawn in a $(3 \mathrm{ml})$ plain tube for cholesterol concentration and (2ml) EDTA tube for blood group making. The age, sex for each individual were recorded. Fasting serum cholesterol done by auto-analyzer spin 120 . ABO blood groups were determined by standard agglutination techniques (Expert Diagnosis $\mathrm{ABO}$ blood group kit made in UAE. All the statistical analysis was done by cori 5 computer to the SPSS program (version-19).Normal value for cholesterol depend on report of the National Cholesterol Education Program [13]:

\begin{tabular}{|l|l|}
\hline $\begin{array}{l}\text { Level of } \\
\text { cholesterol } \\
\text { mmol/L }\end{array}$ & Interpretation \\
\hline$<5.2$ & $\begin{array}{l}\text { Required level to lower danger for } \\
\text { heart disease }\end{array}$ \\
\hline $5.2-6.2$ & Borderline great danger \\
\hline$>6.2$ & High danger \\
\hline
\end{tabular}

\section{Results and Discussion}

One hundred blood - samples from Iraqi people have been collected. Those groups were classified in the table below according to their age range: 


\section{DIYALA JOURNAL FOR PURE SCIENCES}

Study the Relationship Between Level of Cholesterol and Blood Group in Middle Age and Elderly Iraqi People

Hiba Abid Al-Hussein Hassan

Table (1): Distribution of groups according to concentration of cholesterol and age/ years

\begin{tabular}{|c|c|c|c|c|}
\hline \multirow[t]{2}{*}{$\begin{array}{l}\text { Age of Studied } \\
\text { groups/years }\end{array}$} & \multicolumn{3}{|c|}{$\begin{array}{c}\text { Cholesterol } \\
(\mathrm{mmol} / \mathrm{l})\end{array}$} & \multirow[t]{2}{*}{ Total } \\
\hline & $<5.2$ & 5.2-6.2 & $>6.2$ & \\
\hline $\begin{array}{l}\text { Count } \\
\% \text { of Total }\end{array}$ & $\begin{array}{r}4 \\
4.0 \%\end{array}$ & $\begin{array}{r}3 \\
3.0 \%\end{array}$ & $\begin{array}{r}1 \\
1.0 \%\end{array}$ & $\begin{array}{r}8 \\
8.0 \%\end{array}$ \\
\hline $\begin{array}{l}\text { Count } \\
\text { 30-39 } \\
\% \text { of Total }\end{array}$ & $1.0 \%$ & $\begin{array}{r}5 \\
5.0 \%\end{array}$ & $\begin{array}{r}0 \\
.0 \%\end{array}$ & $\begin{array}{r}6 \\
6.0 \%\end{array}$ \\
\hline $\begin{array}{l}\text { Count } \\
40-49 \\
\% \text { of Total }\end{array}$ & $\begin{array}{r}6 \\
6.0 \%\end{array}$ & $\begin{array}{r}15 \\
15.0 \%\end{array}$ & $\begin{array}{r}5 \\
5.0 \%\end{array}$ & $\begin{array}{r}26 \\
26.0 \%\end{array}$ \\
\hline $\begin{array}{l}\text { Count } \\
50-59 \\
\% \text { of Total }\end{array}$ & $\begin{array}{r}4 \\
4.0 \%\end{array}$ & $\begin{array}{r}18 \\
18.0 \%\end{array}$ & $\begin{array}{r}11 \\
11.0 \%\end{array}$ & $\begin{array}{r}33 \\
33.0 \%\end{array}$ \\
\hline $\begin{array}{l}\text { Count } \\
60-70 \\
\% \text { of Total } \\
\end{array}$ & $\begin{array}{r}8 \\
8.0 \%\end{array}$ & $\begin{array}{r}12 \\
12.0 \%\end{array}$ & $\begin{array}{r}7 \\
7.0 \%\end{array}$ & $\begin{array}{r}27 \\
27.0 \%\end{array}$ \\
\hline $\begin{array}{l}\text { Count } \\
\text { Total } \\
\% \text { of Total }\end{array}$ & $\begin{array}{r}23 \\
23.0 \%\end{array}$ & $\begin{array}{r}53 \\
53.0 \%\end{array}$ & $\begin{array}{r}24 \\
24.0 \%\end{array}$ & $\begin{array}{r}100 \\
100.0 \%\end{array}$ \\
\hline
\end{tabular}

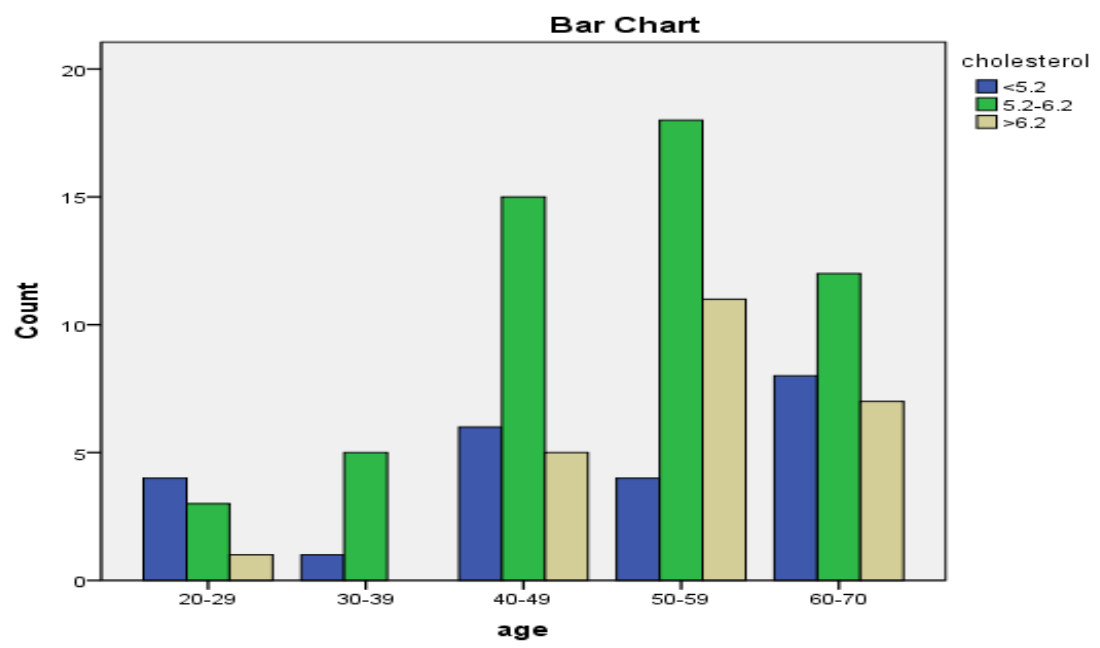

Figure (1): Distribution of group in relation to concentration of cholesterol and age/ years.

This table \& figure showed increase concentration of cholesterol at the age (50-59 and 60-70) years other than age groups. This results agree with other study $[6,14,15,16]$ which observed 


\section{DIYALA JOURNAL FOR PURE SCIENCES}

Study the Relationship Between Level of Cholesterol and Blood Group in Middle Age and Elderly Iraqi People

\section{Hiba Abid Al-Hussein Hassan}

that total cholesterol increases gradually from early adulthood through late middle age, comparatively few studies of either type have examined age-related changes in cholesterol in older populations this may be cholesterol absorption from the intestine increases with age while the excretion of cholesterol in the bile decreases.

Table (2) : Distribution of studied groups in relation to concentration of cholesterol and gender.

\begin{tabular}{|l|r|r|r|r|}
\hline \multirow{2}{*}{ Gender of Studied groups } & \multicolumn{3}{|c|}{ Cholesterol (mmol/l) } & \multirow{2}{*}{ Total } \\
\cline { 2 - 4 } & \multicolumn{1}{|c|}{$<5.2$} & $\mathbf{5 . 2 - 6 . 2}$ & \multicolumn{1}{c|}{$\mathbf{6 . 2}$} & \\
\hline $\begin{array}{l}\text { Female Count } \\
\text { \% of Total }\end{array}$ & $\mathbf{1 6}$ & $\mathbf{3 1}$ & $\mathbf{1 3}$ & $\mathbf{6 0}$ \\
\hline $\begin{array}{l}\text { Male Count } \\
\text { \% of Total }\end{array}$ & $\mathbf{1 6 . 0 \%}$ & $\mathbf{3 1 . 0 \%}$ & $\mathbf{1 3 . 0 \%}$ & $\mathbf{6 0 . 0 \%}$ \\
\hline $\begin{array}{l}\text { Total Count } \\
\text { \% of Total }\end{array}$ & $\mathbf{7 . 0 \%}$ & $\mathbf{2 2}$ & $\mathbf{1 1}$ & $\mathbf{4 0}$ \\
\hline
\end{tabular}

(2)

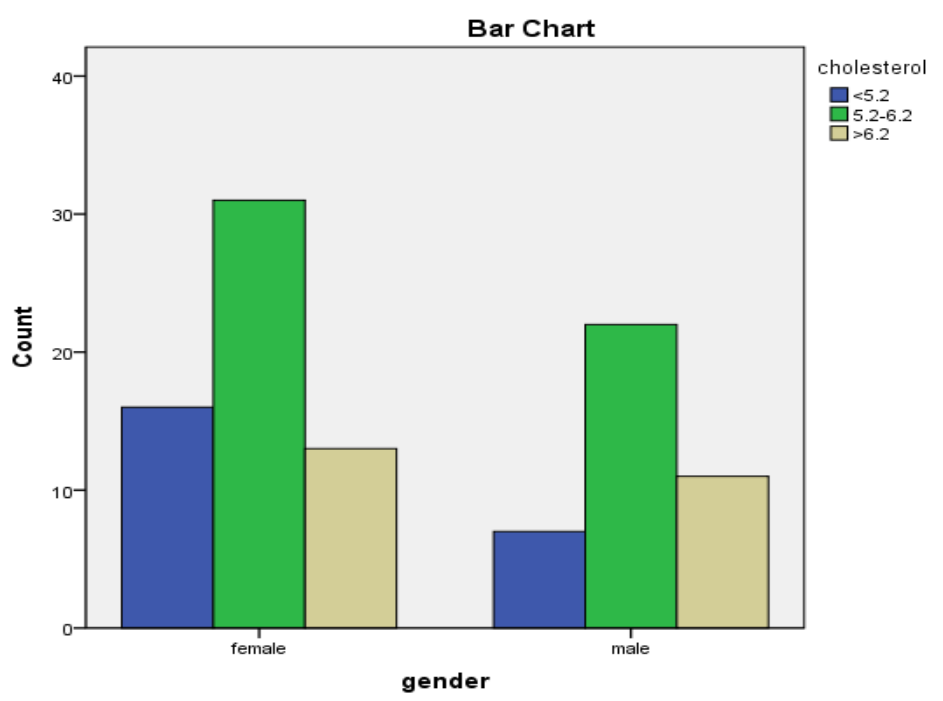

Figure

Distribution of studied groups in relation to concentration of cholesterol and gender. 


\section{DIYALA JOURNAL FOR PURE SCIENCES}

Study the Relationship Between Level of Cholesterol and Blood Group in Middle Age and Elderly Iraqi People

Hiba Abid Al-Hussein Hassan

Table(3):Distribution of studied groups in relation to concentration of cholesterol and blood groups.

\begin{tabular}{|c|c|c|c|c|}
\hline \multirow{2}{*}{$\begin{array}{l}\text { Blood groups of } \\
\text { Studied groups }\end{array}$} & \multicolumn{3}{|c|}{ Cholesterol (mmol/l) } & \multirow[t]{2}{*}{ Total } \\
\hline & $<5.2$ & $5.2-6.2$ & $>6.2$ & \\
\hline $\begin{array}{c}\text { A- } \begin{array}{r}\text { Count } \\
\% \text { of Total }\end{array} \\
\text { \% }\end{array}$ & $\begin{array}{r}0 \\
.0 \%\end{array}$ & $\begin{array}{r}8 \\
8.0 \%\end{array}$ & $\begin{array}{r}3 \\
3.0 \%\end{array}$ & $\begin{array}{r}11 \\
11.0 \%\end{array}$ \\
\hline $\begin{array}{l}\text { Count } \\
\% \text { of Total }\end{array}$ & $\begin{array}{r}10 \\
10.0 \%\end{array}$ & $\begin{array}{r}13 \\
13.0 \%\end{array}$ & $\begin{array}{r}10 \\
10.0 \%\end{array}$ & $\begin{array}{r}33 \\
33.0 \%\end{array}$ \\
\hline $\begin{array}{l}\text { Count } \\
\% \text { of Total }\end{array}$ & $\begin{array}{r}0 \\
.0 \%\end{array}$ & $\begin{array}{r}1 \\
1.0 \%\end{array}$ & $\begin{array}{r}0 \\
.0 \%\end{array}$ & $\begin{array}{r}1 \\
1.0 \%\end{array}$ \\
\hline $\begin{array}{ll}\mathrm{AB}+ & \text { Count } \\
& \% \text { of Total }\end{array}$ & $\begin{array}{r}3 \\
3.0 \%\end{array}$ & $\begin{array}{r}6 \\
6.0 \%\end{array}$ & $\begin{array}{r}2 \\
2.0 \%\end{array}$ & $\begin{array}{r}11 \\
11.0 \%\end{array}$ \\
\hline $\begin{array}{l}\text { Count } \\
\% \text { of Total }\end{array}$ & $\begin{array}{r}0 \\
.0 \%\end{array}$ & $\begin{array}{r}2 \\
2.0 \%\end{array}$ & $\begin{array}{r}0 \\
.0 \%\end{array}$ & $\begin{array}{r}2 \\
2.0 \%\end{array}$ \\
\hline $\begin{array}{ll}\text { B+ } & \text { Count } \\
& \% \text { of Total }\end{array}$ & $\begin{array}{r}7 \\
7.0 \%\end{array}$ & $\begin{array}{r}15 \\
15.0 \%\end{array}$ & $\begin{array}{r}6 \\
6.0 \%\end{array}$ & $\begin{array}{r}28 \\
28.0 \%\end{array}$ \\
\hline $\begin{array}{l}\text { Count } \\
\% \text { of Total }\end{array}$ & $\begin{array}{r}0 \\
.0 \%\end{array}$ & $\begin{array}{r}0 \\
.0 \%\end{array}$ & $\begin{array}{r}2 \\
2.0 \%\end{array}$ & $\begin{array}{r}2 \\
2.0 \%\end{array}$ \\
\hline $\begin{array}{l}\text { Count } \\
\% \text { of Total }\end{array}$ & $\begin{array}{r}3 \\
3.0 \%\end{array}$ & $\begin{array}{r}8 \\
8.0 \%\end{array}$ & $\begin{array}{r}1 \\
1.0 \%\end{array}$ & $\begin{array}{r}12 \\
12.0 \%\end{array}$ \\
\hline $\begin{array}{l}\text { Total Count } \\
\% \text { of Total }\end{array}$ & $\begin{array}{r}23 \\
23.0 \%\end{array}$ & $\begin{array}{r}53 \\
53.0 \%\end{array}$ & $\begin{array}{r}24 \\
24.0 \%\end{array}$ & $\begin{array}{r}100 \\
100.0 \%\end{array}$ \\
\hline
\end{tabular}

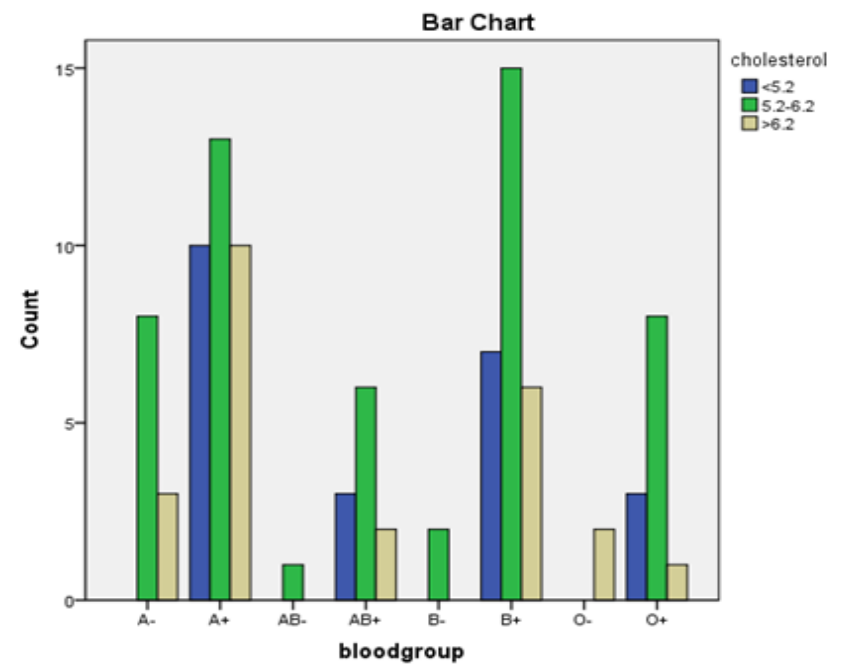

Figure (3) : Distribution of studied groups in relation to concentration of cholesterol and blood groups. 
Study the Relationship Between Level of Cholesterol and Blood Group in Middle Age and Elderly Iraqi People

\section{Hiba Abid Al-Hussein Hassan}

Table and figure (3) appeared that concentration of cholesterol increased at the blood group $\mathrm{A}+(33 \%), \mathrm{B}+(28 \%), \mathrm{O}+(12 \%)$ and $\mathrm{AB}+(11 \%)$ compared with other blood groups this results agree with other studies who detected a greatly increased danger of occurrence coronary heart disease for accomplices with blood group $\mathrm{A}$ or $\mathrm{B}$ or $\mathrm{AB}$, matched with those with blood group O. The tools responsible for causes relationship between "ABO blood group" and heart disease risk stay uncertain. On the other hand, numerous outlines of sign support its possible cardiovascular effects. "ABO blood group" have relationship with serum lipid levels; in general, the "A blood group" have observed to have" increased levels of serum total cholesterol" $[15,16]$. Recently, some genome-wide relationship studies observed that alternates at "ABO locus "was correlated to plasma lipid levels[17,18,6]

\section{Conclusions}

The present study showed increase concentration of cholesterol at the age (50-59 and 60-70) years other than age groups and observed that increased the percentage of concentration of cholesterol in female $(60 \%)$ more than male $(40 \%)$. Also appeared that concentration of cholesterol increased at the blood group $\mathrm{A}+(33 \%), \mathrm{B}+(28 \%), \mathrm{O}+(12 \%)$ and $\mathrm{AB}+(11 \%)$ other than blood groups.

\section{$\underline{\text { References }}$}

1. Genest, J; Frohlich, J, Fodor, G, McPherson, R.2003 Working Group on Hypercho lesterolemia and Other, Dyslipidemias ."Recommendations for the management of dyslipidemia and the prevention of cardiovascular disease: summary of the 2003 update". Canadian Medical Association Journal169 (9): 921-4.

2. Biggerstaff KD, Wooten JS . 2004 "Understanding lipoproteins as transporters of cholesterol and other lipids". AdvPhysiolEduc 28 (1-4): 105-6. 
Study the Relationship Between Level of Cholesterol and Blood Group in Middle Age and Elderly Iraqi People

\section{Hiba Abid Al-Hussein Hassan}

3. Howell WH, McNamara DJ, Tosca MA, Smith BT, Gaines JA. 1997 "Plasma lipid and lipoprotein responses to dietary fat and cholesterol: a meta-analysis". Am. J. Clin. Nutr.65 (6): 1747-64.

4. Franchini M, Favaloro EJ, Targher G, Lippi G.2012 "ABO blood group, hypercoagulability, and cardiovascular and cancer risk". Crit Rev Clin Lab Sci. 49:137149.

5. Olson RE. 1998 "Discovery of the lipoproteins, their role in fat transport and their significance as risk factors". J. Nutr.128 (2 Suppl): 439S-443S.

6. Meian He, Brian Wolpin, Kathy Rexrode, etal. 2012 "ABO Blood Group and Risk of Coronary Heart Disease in Two Prospective Cohort Studies" Arterioscler Thromb Vasc Biol. Sep; 32(9): 2314-2320.

7. Lecerf JM, de Lorgeril M. 2011"Dietary cholesterol: from physiology to cardiovascular risk". Br J Nutr106 (1): 6-14.

8. Dubois C, Armand M, Mekki N, Portugal H, Pauli AM, Bernard PM et al.1994 "Effects of increasing amounts of dietary cholesterol on postprandial lipemia and lipoproteins in human subjects". Journal of LIPID Research 35 ,1993-2007.

9. Ohvo-Rekilä H, Ramstedt B, Leppimäki P, Slotte JP,2002 "Cholesterol interactions with phospholipids in membranes". Prog. Lipid Res.41 (1): 66-97.

10. Wong FL, Kodama K, Sasaki H, Yamada M, Hamilton HB. 1992 " Longitudinal study of the association between $\mathrm{ABO}$ phenotype and total serum cholesterol level in a Japanese cohort". Genet Epidemiol ,9(6):405-41819.

11. Storry JR, Olsson ML. 2009 "The ABO blood group system revisited: a review and update" Immunohematology.,25:48-59.

12. Favaloro EJ1, Soltani S, McDonald J, Grezchnik E, Easton L, Favaloro JW. 2005 "Reassessment of ABO blood group, sex, and age on laboratory parameters used to diagnose von Willebrand disorder: potential influence on the diagnosis vs the potential association with risk of thrombosis". Am J Clin Pathol. Dec;124(6):910-7. 
Study the Relationship Between Level of Cholesterol and Blood Group in Middle Age and Elderly Iraqi People

\section{Hiba Abid Al-Hussein Hassan}

13. "Report of the National Cholesterol Education Program Expert Panel on Detection, Evaluation, and Treatment of High Blood Cholesterol in Adults. The Expert Panel" 1988 Arch. Intern. Med. 148 (1): 36-69.

14. Einarsson K, Nilsell K, Leijd B, et al.1985" Influence of age on secretion of cholesterol and synthesis of bile acids by the liver". N Engl J Med ,313:277-82.

15. Miller NE. 1984 "Why does plasma low density lipoprotein concentration in adults increase with age?" Lancet, 1:263-6.20.

16. Craig J. Newschaffer, Trudy L. Bush, and William E. Hale. 1992 "Aging and Total Cholesterol Levels: Cohort, Period, and Survivorship Effects" American Journal of Epidemiology 136, 1.23-43.

17. Teslovich TM, Musunuru K, Smith AV, Edmondson AC etal. 2010 "Biological, clinical and population relevance of 95 loci for blood lipids". Nature. 466:707-713.

18. Chasman DI, Pare G, Mora S, Hopewell JC, Peloso G, etal. 2009 " Forty-three loci associated with plasma lipoprotein size, concentration, and cholesterol content in genome-wide analysis" PLoS Genet.5:e1000730 . 